\title{
STRATEGI KEUCHIK SEBAGAI PELAYAN PUBLIK DALAM MENINGKATKAN PARTISIPASI MASYARAKAT
}

\author{
Aduwina Pakeh \\ Fakultas Ilmu Sosial dan Ilmu Politik, Universitas Teuku Umar \\ aduwina@utu.ac.id
}

\begin{abstract}
This paper aims to explain the alternative strategies that can be done by the Village Head (Keuchik) as public servants, especially those related to the service of population administration. Public services should continue to be improved and involve recipients of services. The problem is in the service process, in addition to the quality is still low, the public as recipients of services rarely included. The methods used in this study are qualitative and secondary data. It is found that there are at least two strategies that can be done in order to improve the service and public participation, such as the Citizen Charter and the application of information and communication technology. Based on these findings, Keuchik as public servant is expected to implement both strategies in providing and improving public services.
\end{abstract}

Keywords: village, strategy, village head, public service, participation 


\section{PENDAHULUAN}

Tujuan daripada tulisan ini untuk memberikan beberapa alternatif strategi pelayanan publik, khususnya pelayanan administrasi kependudukan yang dapat dilakukan oleh Keuchik bersama perangkat gampong. Hal ini menjadi penting, mengingat tuntutan Undang-Undang Nomor 06 Tahun 2014 Tentang Desa, iaitu bagaimana membangun dan membina masyarakat Desa/gampong sesuai dengan prakarsa masyarakat. Keluarnya UU Desa ini merupakan lanjutan dari reformasi Administrasi Publik.

Reformasi Administrasi Publik yang ditungkan melalui Undang-Undang Nomor 22. Tahun 1999 Tentang Otonomi Daerah sebagaimana diubah menjadi UU Nomor 32 Tahun 2004, kemudian disempurnakan menjadi UU 23 Tahun 2014 tentang Pemerintahan Daerah telah membawa perubahan drastis dalam pengelolaan tata pemerintahan termasuk pelayanan publik. Segala sesuatu yang tadinya bersifat sentralistik berubah menjadi desentralistik. Bidang-bidang tugas yang sebelumnya semua dipegang oleh pemerintah pusat berubah menjadi hanya enam bidang tugas saja, selebihnya menjadi wewenang daerah kabupaten/kota.

Reformasi Administrasi Publik ini tidka hanya terjadi dilevel Kabupaten/Kota saja, melainkan juga hingga di level gampong. Meskipun kewenangan gampong sempat terdegradasi akibat perubahan pengaturannya dari Undang-Undang tersendiri menjadi bagian dari UndangUndang Pemerintah Daerah, akan tetapi melalui UU No 6 Tahun 2014, posisi Desa kembali diperkuat. Melalui UU ini status dan kepastian hukum atas Desa dalam system ketatanegaraan Republik Indonesia menjadi lebih jelas.

Selain itu, kewenangan desa pun semakin dipertegas seperti kewenangan di bidang penyelenggaraan pemerintahan Desa, pelaksanaan pembangunan Desa, pembinaan kemasyarakatan Desa, pemberdayaan masyarakat Desa berdasarkan prakarsa masyarakat, hak asal usul, dan adat istiadat Desa, dan kewenangan yang ditugaskan oleh pemerintah, pemerintah daerah provinsi, atau pemerintah daerah Kabupaten/Kota. Kewenangan-kewenangan ini seluruhnya menjadi tanggungjawab Keuchik / Kepala Desa. Itu berarti, sukses tidaknya penyelenggaraan berbagai kewenangan dimaksud berada di pundak Keuchik. Akan tetapi, kewenangan itu tentunya akan mengalami berbagai-bagai hambatan apabula Keuchik melakukannya sendiri. Bantuan oleh perangkat gampong pun tidak akan cukup untuk menyelenggarakan seluruh kewenangan itu dengan baik. Dengan demikian, partisipasi masyarakat tentunya sangat dibutuhkan.

Pemerintahan terbukan (open government) di level gampong bagaimanapun memang harus dilakukan. Melalui pemerintahan terbuka, masyarakat akan memiliki ruang untuk memberikan partisipasinya. Keuchik pun harus merubah cara berfikirnya yang semula sebagai penguasa menjadi sebagai pelayan masyarakat. Keuchik bersama perangkat gampong harus mampu menggerakkan partisipasi masyarakat dalam melaksanakan pembangunan, khususnya dalam pelayanan publik.

Pelayanan public tidak dapat lagi hanya dilakukan melalui cara-cara konvensional, iaitu hanya dimonopoli oleh Keuchik bersama perangkatnya saja, melainkan melalui strategi baru seperti pelibatan masyarakat. Pola administration of public, yakni Keuchik dan perangkatnya yang paling mengetahui apa yang menjadi kebutuhan masyarakat harus dirubah menjadi administration by public, yakini masyarakatlah yang paling mengetahui kebutuhannya. Dengan demikian, sangat beralasan bahwa masyarakat harus dilibatkan dalam setiap perencanaan pembangunan di daerahnya, termasuk dalam merancang model pelayanan public di gampong.

\section{Pelayanan Publik}

Secara sederhana dalam arti konsep pelayanan berarti membicarakan tentang cara yang dilakukan untuk memberikan servis atau jasa kepada orang yang membutuhkan. Dalam artian secara etimologis, kata publik berasal dari bahasa inggris, yakni public berarti masyarakat, umum, rakyat umum, orang banyak, dan keperluan umum. Dalam bahasa Indonesia, publik 
berarti orang banyak (umum). Dengan demikian, pelayanan publik merupakan kegiatan membantu masyarakat (stakeholders) dalam rangka memperoleh servis dan advis yang terkait dengan kepentingan umum (orang banyak)

Pelayanan publik merupakan proses pemenuhan kebutuhan melalui aktivitas orang lain secara langsung kepada mereka yang membutuhkannya. Konsep ini merupakan konsep yang actual dalam berbagai aspek kelembagaan. Tidak saja dalam organisasi bisnis, namun konsep ini telah berkembang lebih luas pada tatanan organisasi pemerintah.

Mengikuti pandangan Laing (2003), sebagaimana dikutip purwanto (2005) dan Marlan (2016), menyebutkan ada beberapa karakteristik yang dapat dipakai untuk mendefinisikan apa yang dapat dikategorikan sebagai pelayanan public secara lebih terperinci. Pertama, dalam kegiatan penyediaan barang dan jasa yang dibutuhkan masyarakat, pelayanan public dicirikan oleh adanya pertimbangan untuk mencapai tujuan politik yang lebih besar dibanding dengan upaya untuk mewujudkan tujuan ekonomis. Hal ini tentunya berbeda dengan pertimbangan ekonomi yang lebih dikedepankan oleh organisasi swasta. Pelayanan oleh pemerintah dilakukan lebih kepada perwujudan keadilan sosial (sosial equality) bagi masyarakat. Berdasarkan pada karakteristik yang demikian, maka tujuan pelayanan public selanjutnya tidak hanya dipahami sebagai upaya untuk memenuhi kebutuhan masyarakat yang membutuhkan, namun lebih dari itu, pelayanan public juga dimaksudkan untuk memberi manfaat sosial yang lebih luas.

Kedua, pelayanan publik juga dicirikan oleh adanya asumsi bahwa penggunaan layanan lebih dilihat posisinya sebagai warga Negara daripada hanya dilihat sebagai pengguna pelayanan (customer) semata. Asumsi ini sebenarnya merupakan konsekuensi lebih lanjut dari karakteristik pelayanan publik yang pertama sebagaimana telah disinggung di depan. Oleh karena itu tugas pemerintah tidak semata mencari keuntungan, maka hubungan antara pemerintah dengan pengguna jasa juga tidak dapat dilihat sebagai hubungan yang bersifat resiprokal antara penarik pajak (pemerintah) dan pembayar pajak (masyarakat), sebagaimana hubungan antara penjual dan pelanggannya seperti yang lazim dijumpai di sector swasta.

Ketiga, pelayanan publik juga dicirikan oleh karakter pengguna layanan yang kompleks dan multidimensional. Multidimensionalitas tersebut tercermin dari level pemanfaat layanan yang bisa bersifat individu, keluarga, maupun komunitas. Sebagai ilustrasi, dalam beberapa jenis pelayanan publik, seperti pendidikan atau pelayanan dalam bidang sosial, orang yang memperoleh manfaat dari program tersebut tidak hanya orang yang membiayai pelayanan (para pembayar pajak) dengan orang yang memperoleh layanan publik yang disediakan oleh pemerintah. Pemerintah mempunyai peran sebagai redistributor sumberdaya yang ada dalam masyarakat iaitu dengan menarik pajak dari pihak yang mampu (kaya) dan mendistribusikannya kepada pihak yang kurang mampu (miskin). Dengan dimilikinya sumber finansial dari pajak ini memungkinkan bagi pemerintah untuk menyelenggarakan pelayanan yang bersifat sosial seperti pelayanan dalam bidang kesehatan, pendidikan dan lain-lain.

Pelayanan publik diseluruh daerah provinsi serta kabupaten/kota di Indonesia telah memperoleh landasan konstitusional, iaitu diatur dalam Pasal 18A UUD NRI Tahun 1945. Ketentuan tersebut selanjutnya diimplementasikan melalui UU pelayanan publik. Dengan demikian, UU Pelayanan Publik ini sudah seharusnya dalam tataran normatif harus menterjemahkan atau mengimplementasikan keinginan esensi fasal 18A UUD NRI 1945. Dalam pengertian bahwa, ketentuan pasal ini harus memuat prinsip-prinsip dasar yang memungkinkan bagi terselenggaranya pelayanan pada masyarakat yang lebih dapat dinikmati oleh masyarakat.

Dalam Undang-Undang Nomor 25 Tahun 2009 tentang Pelayanan Publik, Pasal 1 Angka 1 dirumuskan: "pelayanan publik adalah kegiatan atau rangkaian kegiatan dalam rangka pemenuhan kebutuhan pelayanan sesuai dengan peraturan perundang-undangan bagi setiap warga Negara dan penduduk atas barang, jasa dan/atau pelayanan administrasi yang disediakan oleh penyelenggara pelayanan publik. Dengan demikian tugas utama dari setiap instansi 
pemerintahan adalah memberikan pelayanan atau menyelenggarakan pelayanan publik (public service) dan kesejahteraan bagi rakyatnya (public welfare) berdasarkan peraturan perundangundangan (Busrizalti, 2013).

Berkaitan dengan pengertian tentang pelayanan publik di atas, maka dapat ditarik suatu pemahaman bahwa pelayanan publik adalah segala bentuk jasa pelayanan, baik dalam bentuk barang publik maupun jasa publik yang menjadi tanggung jawab dan dilaksanakan oleh institusi pemerintah pusat dan atau daerah dalam rangka pemenuhan kebutuhan masyarakat maupun dalam rangka pelaksanaan ketentuan peraturan perundang-undangan. Dengan demikian jelas bahwa tidak ada alasan untuk menghambat penyelenggaraan publik terhadap masyarakat oleh aparatur pemerintah baik di pusat maupun di daerah.

\section{Pelayanan Publik Partisipatif}

United Nations Development Programme atau UNDP (2015) melaporkan bahwa nilai Human Development Index (HDI) Indonesia 0,684 dan menempati rangkin 113 dari 187 negara yang dinilai. Kondisi tersebut dapat menggambarkan pelayanan publik dalam bidang pendidikan, kesehatan dan bidang kehidupan yang lain masih buruk dibandingkan negara lainnya. World Bank (2011) dalam laporannya mengenai kemudahan menjalankan bisnis (Ease of Doing Bussiness) memeringkatkan Indonesia di posisi 129 dari 183 negara yang dinilai. Kondisi ini menggambarkan bahwa pelayanan publik yang diberikan kepada pelaku usaha masih buruk dibandingkan pelayanan publik yang diberikan negara lainnya.

Puspitosari dkk. (2011:131) menyatakan bahwa buruknya pelayanan publik diakibatkan oleh minimnya partisipasi masyarakat dalam perbaikan pelayanan publik. Untuk itu perlu dilakukan langkahlangkah untuk meningkatkan partisipasi masyarakat dalam perbaikan pelayanan publik (Dwiyanto, 2011:89-90). Pemerintah telah memberikan perhatian khusus terhadap partisipasi masyarakat dalam perbaikan pelayanan publik. Hal ini dibuktikan dengan dikeluarkannya Permenpan 13/2009 Tentang Pedoman Peningkatan Kualitas Pelayanan Publik Dengan Partisipasi Masyarakat, yang memberikan pedoman terhadap pelaksanaan partisipasi masyarakat dalam pelayanan publik. Menurut data Kemenpan dan RB pada tahun 2009, Permenpan No. 13/2009 telah dilakukan di 75 lembaga Pemerintahan atau dalam hal ini penyelenggara pelayanan publik. Baik itu penyelenggara pelayanan publik di tingkat Pemerintah Pusat maupun di tingkat Pemerintah Daerah. Pelaksanaan Permenpan No. 13/2009 pada penyelenggara pelayanan publik tersebut dilakukan pada 485 unit pelayanan publik. Namun, apakah partisipasi masyarakat dalam perbaikan pelayanan publik khususnya melalui pelaksanaan Permenpan No. 13/2009 ini telah efektif memperbaiki pelayanan publik. Berdasarkan hal tersebut penelitian ini ditujukan untuk mengidentifikasi efektifitas partisipasi masyarakat dalam perbaikan pelayanan publik dan mengidentifikasi faktor-faktor yang mempengaruhinya.

Partisipasi masyarakat adalah tindakan ikut serta sekumpulan individu dalam sebuah kegiatan yang dilakukan oleh Pemerintah. Partisipasi masyarakat dilahirkan dari konsep pemberdayaan masyarakat. Pada konsep tersebut masyarakat dilibatkan dalam setiap kegiatan pembangunan yang dilakukan oleh Pemerintah. Termasuk dalam perbaikan pelayanan publik. Seiring dengan tujuan partisipasi tersebut, yaitu memberdayakan masyarakat secara optimal, Sherry Arnstein (1969) merumuskan 8 (delapan) anak tangga partisipasi masyarakat yang dibagi kedalam 3 (tiga) tingkatan. Berikut penjelasan masing-masing anak tangga yang dikembangkan oleh Arnstein dapat dilihat pada tabel 1 
Tabel 1. Tingkatan Partisipasi Masyarakat

\begin{tabular}{|c|l|c|}
\hline No & Anak Tangga & Tingkat \\
\hline 1 & Kontrol oleh warga Negara & \multirow{2}{*}{ Kekuatan Masyarakat } \\
\hline 2 & Pendelagasian wewenang & \\
\hline 3 & Kemitraan & \multirow{2}{*}{ Tokenism } \\
\hline 4 & Placation & \multirow{2}{*}{ Tidak Berpartisipasi } \\
\hline 5 & Konsultasi & \\
\hline 6 & Pemberian Informasi & Terapi
\end{tabular}

Sumber: Diolah peneliti dari berbagai sumber

Tingkatan terbawah dari 8 (delapan) anak tangga partisipasi masyarakat adalah tidak berpartisipasi. Pada tingkatan ini partisipasi masyarakat tidak bertujuan untuk membuat masyarakat berpartisipasi tapi bertujuan untuk mengedukasi masyarakat. Pada tingkatan ini terdapat dua anak tangga, yaitu terapi dan manipulasi. Manipulasi merupakan tindakan Pemerintah untuk mempengaruhi perilaku, sikap, dan pendapat orang lain tanpa orang itu menyadarinya. Terapi merupakan usaha untuk memulihkan kesehatan orang yang sedang "sakit". "Sakit" disini bukanlah arti sebenarnya, melainkan kekecewaan atas program maupun kegiatan pemerintah sehingga Pemerintah melakukan terapi untuk mengobati kekecewaan masyarakat dengan mendengarkan keluhan, menjamin tidak terjadi lagi kesalahan, dan lainnya (Arnstein, 1969).

Pada tingkatan menengah 8 (delapan) anak tangga partisipasi masyarakat adalah tokenism. Tokenism merupakan kondisi dimana masyarakat diminta pendapatnya atau diberikan informasi mengenai suatu keputusan, namun masyarakat tidak memiliki kekuatan untuk mempengaruhi keputusan tersebut (Ife dan Tesoriero, 2008:306-309). Masyarakat mendengarkan informasi yang disampaikan oleh Pemerintah dan masukan yang diberikan oleh masyarakat didengarkan oleh Pemerintah. Namun, tidak dapat dipastikan masukan dari masyarakat tersebut diperhatikan oleh Pemerintah karena kekuatan pengambilan keputusan masih berada ditangan Pemerintah.

Pada tingkatan ini terdapat 3 (tiga) anak tangga, yaitu (1) pemberian informasi; (2) konsultasi; dan (3) placation. Pemberian informasi merupakan proses menjelaskan hak, tanggung jawab, pilihan, atau hal lain yang berkaitan dengan keputusan yang diambil oleh Pemerintah kepada masyarakat. Namun, pemberian informasi ini tidak diikuti oleh saluransaluran untuk memberikan tanggapan atas informasi yang diterima. Konsultasi merupakan proses pertukaaran pikiran untuk mendapatkan kesimpulan yang sebaik- baiknya. Namun, konsultasi yang dimaksudkan dalam anak tangga ini hanyalah ritual untuk meyakinkan bahwa partisipasi masyarakat telah dilakukan. Pemerintah hanya menggunakan data maupun informasi mengenai berapa jumlah masyarakat yang datang, berapa kuisioner yang telah diisi, dan data partisipasi lainnya. Pemerintah tidak menjamin apa yang dilakukan masyarakat dalam konsultasi tersebut akan diperhitingkan dalam proses pengambilan keputusan. Placation merupakan proses membebaskan atau memberikan kesempatan kepada masyarakat secara terbatas untuk ikut memberikan masukan maupun input lain yang berguna bagi pengambilan keputusan. Masyarakat yang berpartisipasi ditentukan oleh Pemerintah serta pengambilan keputusan tetap berada ditangan Pemerintah (Arnstein, 1969).

Pada tingkat tertinggi 8 (delapan) anak tangga partisipasi masyarakat adalah kekuatan masyarakat. Pada tingkatan ini masyarakat menjadi salah satu kekuatan atau menjadi aktor utama dalam melakukan sebuah kegiatan. Pada tingkatan ini terdapat 3 (tiga) anak tangga, yaitu: (1) kemitraan; (2) pendelegasian wewenang; dan (3) kontrol masyarakat. Kemitraan merupakan bentuk kerjasama antara pemerintah dengan masyarakat. Kewenangan didistribusikan kepada masyarakat dan Pemerintah dengan mekanisme negosiasi dan persetujuan kedua belah pihak. 
Kewenangan tersebut dari perencanaan sampai dengan pengambilan keputusan. Pendelegasian Wewenang merupakan bentuk pembagian wewenang yang jelas antara Pemerintah dengan masyarakat. Namun, porsi wewenang yang besar berada di masyarakat dibandingkan Pemerintah. Kontrol masyarakat merupakan pemberian kewenangan yang lebih besar dalam pengambilan keputusan sehingga masyarakat diberikan sumberdaya yang memadai untuk berpartisipasi. Masyarakat melakukan sendiri pengelolaan kegiatan, dari proses perencanaan hingga pertanggung jawaban (Arnstein, 1969).

\section{Partisipasi Masyarakat Dalam Perbaikan Pelayanan Publik}

Saat ini kondisi pelayanan publik masih memprihatinkan. Partisipasi masyarakat dalam perbaikan pelayanan publik dianggap menjadi salah satu cara untuk memperbaiki pelayanan publik. Untuk itu Pemerintah mengeluarkan Permenpan No. 13/2009 sebagai pedoman untuk melaksanakan partisipasi masyarakat dalam perbaikan pelayanan publik.

Permenpan dilakukan dalam lima tahapan yang saling berkaitan satu dengan yang lainnya. Tahapan tersebut yaitu: (1) penataan awal; (2) lokakarya pengaduan masyarakat; (3) survei pengaduan masyarakat; (4) lokakarya analisis masalah penyebab pengaduan masyarakat dan rencana tindak nyata; dan (5) pemantauan dan evaluasi.

Pada tahapan penataan awal dilakukan langkah-langkah persiapan pelaksanaan Permenpan No. 13/2009, seperti meyakinkan penyelenggara pelayanan agar bersedia melaksanakan Permenpan No. 13/2009, mempersiapkan sumberdaya pendukung, dan hal lainnya.

Pada tahapan lokakarya pengaduan masyarakat dilakukan inventarisasi pengaduan masyarakat untuk mengetahui kondisi pelayanan publik. Masyarakat, penyelenggara pelayanan publik, dan pelaksana pelayanan publik pada organisasi penyelenggara pelayanan publik dilibatkan. Lokakarya ini menghasilkan sejumlah pengaduan yang akan dimasukan kedalam kuisioner pengaduan masyarakat.

Tahapan survei pengaduan masyarakat dilakukan untuk mengkonfirmasi pengaduan yang ada dalam kuisioner pengaduan masyarakat yang dihasilkan pada tahapan sebelumnya kepada sebanyak mungkin masyarakat. Hasil dari survei ini adalah Indeks Pengaduan Masyarakat (IPM) yang menggambarkan urutan pengaduan masyarakat dari yang terbanyak diadukan sampai dengan yang paling sedikit diadukan.

Pada lokakarya analisis masalah penyebab pengaduan masyarakat dan rencana tindak nyata dilakukan analisis penyebab pengaduan dengan menggunakan dasar IPM dari tahap sebelumnya. Peserta terdiri atas masyarakat, penyelenggara pelayanan publik, dan pelaksana pelayanan publik dari organisasi penyelenggara pelayanan publik. Para peserta secara bersamasama menganalisis penyebab pengaduan masalah dan solusi yang dapat dilakukan untuk mengatasi permasalahan tersebut. Solusi yang dapat dilakukan oleh organisasi penyelenggara pelayanan publik dituangkan ke dalam Janji Perbaikan Pelayanan (JPP) dan solusi yang tidak dapat dilakukan oleh organisasi penyelenggara pelayanan publik namun dapat dilakukan oleh penyelenggara pelayanan publik di tuangkan kedalam Rekomendasi Perbaikan Pelayanan (RPP).

Tahapan selanjutnya adalah pemantauan dan evaluasi. Pada tahap ini pelaksanaan JPP dan RPP dipantau dan dievaluasi. Untuk memperoleh informasi mengenai pelaksanaan JPP dan RPP sekaligus melakukan langkahlangkah yang dapat diperlukan untuk mewujudkan JPP dan RPP tersebut.

\section{METODOLOGI PENELITIAN}

Jenis penelitian ini adalah penelitian deskriptif kualitatif. Penelitian deskriptif adalah penelitian yang memaparkan dan bertujuan memberikan gambaran serta menjelaskan dari variabel yang diteliti. Sedangkan menurut Moleong (2007:6) mengemukakan bahwa deskriptif adalah data yang dikumpulkan berupa data-data, gambar, dan bukan angka-angka. 
Fokus penelitian ini adalah untuk mengetahui strategi keuchik sebagai pelayan publik dalam meningkatkan partisipasi dan pelayanan publik. Data yang digunakan adalah data sekunder.

\section{HASIL DAN PEMBAHASAN \\ Kontrak Pelayanan dan Penerapan Teknologi Informasi dan Komunikasi Sebagai Strategi Peningkatan Pelayanan Publik}

\section{A. Kontrak Pelayan (Citizen Charter)}

Citizen Charter diperkenalkan pertama kali di Inggris pada waktu Perdana Menteri Margareth Thatcher. Pada awalnya merupakan sebuah dokumen yang di dalamnya memuat hakhak dan kewajiban-kewajiban yang melekat baik dari dalam diri providers maupun bagi customers. Kemudian dalam perkembangannya, dalam dokumen tersebut disebutkan pula sanksi-sanksi terhadap pelanggaran apabila salah satu pihak tidak mampu menjalankan kewajibannya sesuai dengan ketentuan dalam dokumen Citizen Charter tersebut. Kemudian seiring dengan perkembangan konsep dan teori dalam Manajemen Strategis, dalam Citizen Charter ditambahkan pula visi dan misi organisasi penyelenggara pelayanan dan juga visi dan misi pelayanan organisasi tersebut. Istilah Citizen Charter pada mulanya ditujukan untuk pengguna jasa atau clien saja (customers atau client), bukan untuk seluruh warga negara (citizen). Namun, istilah yang salah kaprah ini ditujukan tetap untuk seluruh masyarakat sebagai pengguna jasa. Citizen Charter sering juga disebut sebagai customer's charter, client's charter. Dalam padanan kata yang tepat dari Citizen Charter dalam bahasa Indonesia, salah satu terjemahan yang kiranya dapat mewakili makna sering disebut dengan "Kontrak Pelayanan".

Osborne dan Plastrik (1997, 2004) memperkenalkan lebih lanjut Citizen Charter untuk mengembalikan kepercayaan public terhadap pemerintah. Ide ini berasal dari apa yang dilakukan oleh John Major pemimpin konservatif di Inggris. Strategi baru ini diluncurkan Major pada bulan Juli 1991. Citizen Charter berisikan adanya standar pelayanan public yang ditetapkan berdasarkan masukan pelanggan /warga Negara, dan aparatur pemerintah berjanji untuk memenuhinya. Melalui strategi ini warga Negara memiliki hak-hak baru apabila dirugikan oleh aparatur pemerintah dalam memberikan pelayanan.

Citizen Charter atau kontrak pelayanan merupakan pendekatan baru dalam pelayanan publik yang menempatkan pengguna layanan sebagai pusat perhatian atau unsur yang paling penting. Melalui kontrak pelayanan diharapkan akan dapat membentuk budaya melayani, seperti dalam konsep birokrat sebagai pamong praja dan bukannya pangreh praja. Dalam konteks ini, kebutuhan dan kepentingan pengguna layanan menjadi pertimbangan utama dalam keseluruhan proses pemberian layanan. Di dalam praktik, kontrak pelayanan digunakan untuk mendorong penyedia layanan, pengguna layanan dan stakeholders (pemangku kepentingan, pemegang kunci) lainnya untuk membuat "kesepakatan bersama" tentang jenis, prosedur, biaya, waktu dan cara memberikan pelayanan. Tujuan dari terbentuknya lontrak pelayanan memang untuk membuat agar pelayanan publik menjadi lebih tanggap atau responsif, transparan dan bertanggungjawab atau akuntabel, maka perumusan kontrak kelayanan itu harus melibatkan para pengguna layanan, seluruh satuan yang terlibat dalam penyediaan layanan, Lembaga Swadaya Masyarakat (LSM), Lembaga Dewan Perwakilan Rakyat Kabupaten (DPRK), tokoh masyarakat lokal, dan lain-lainnya. Fungsionalitas dalam kontrak pelayanan terlihat bahwa ia akan dapat dijadikan sebagai bentuk rumusan dari kesepakatan bersama yang bersifat terbuka, sebagai instrumen publik untuk mengontrol penyelenggaraan pelayanan, dan juga sebagai sarana untuk mengatur hak dan kewajiban dari pengguna maupun penyedia pelayanan secara seimbang dan adil. Dengan demikian asumsi yang terdapat di dalam good governance sangat sejalan dengan kontrak pelayanan, yaitu bahwa pelayanan public akan menjadi urusan dan tanggung jawab bersama antara pemerintah, swasta, dan masyarakat pengguna pada umumnya. Untuk konteks negara-negara maju, Citizen Charter juga telah menjadi bagian penting dari The 
Charter of Fundamental Rights di Uni Eropa, bahkan di India dan Malaysia sekalipun Negara tersebut sesungguhnya telah lama menerapkan citizen charter dalam penyelenggaraan proses pelayanan publik.

Adapun hasil dari ujicoba di beberapa daerah di Indonesia membuktikan bahwa penerapan Citizen Charter ini banyak manfaat yang akan dirasakan, baik oleh birokrasi, pengguna layanan, maupun stakeholders pengguna lainnya. Manfaat tersebut antara lain: Pertama, dapat memberikan kepastian pelayanan yang meliputi waktu, biaya, prosedur dan cara pelayanan. Kedua, untuk memberikan informasi mengenai hak dan kewajiban pengguna layanan, penyedia layanan, dan stakeholder lainnya dalam keseluruhan proses penyelenggaraan pelayanan. Ketiga, untuk mempermudah pengguna layanan, warga, dan stakeholder lainnya mengontrol praktek penye-lenggaraan pelayanan. Keempat, untuk mempermudah manajemen pelayanan memperbaiki kinerja penyelenggaraan pelayanan. Kelima, untuk membantu manajemen pelayanan mengidentifikasi kebutuhan, harapan dan aspirasi pengguna layanan dan stakeholders lainnya.

Selanjutnya, ada lima unsur pokok yang biasanya tercantum di dalam Kontrak Pelayanan (Citizen Charter), yaitu:

1) Visi dan misi pelayanan; Yang termuat di sini adalah rumusan tentang sejauhmana organisasi pelayanan publik telah merujuk pada prinsip-prinsip kepastian pelayanan. Visi dan misi pelayanan tidak harus selalu difahami sebagai slogan atau motto, tetapi harus diaktualisasikan ke dalam tindakan konkret. Visi dan misi harus menjadi bagian dari budaya pelayanan yang tercermin di dalam cara pemberian layanan;

2) Standar pelayanan; Berisi penjelasan tentang apa, mengapa dan bagaimana upaya yang diperlukan untuk memperbaiki kualitas pelayanan. Standar pelayanan memuat normanorma pelayanan yang akan diterima oleh pengguna layanan. Dalam hal ini standar pelayanan harus memuat standar perlakuan terhadap pengguna, standar kualitas produk (out-put) yang diperoleh masyarakat dan standar informasi yang dapat diakses oleh pengguna layanan;

3) Alur pelayanan; Berisi penjelasan tentang unit/ bagian yang harus dilalui bila akan mengurus sesuatu atau menghendaki pelayanan dari organisasi publik tertentu. Alur pelayanan harus menjelaskan berbagai fungsi dan tugas unit-unit dalam kantor pelayanan sehingga kesalahpahaman antara penyedia dan pengguna jasa pelayanan dapat dikurangi. Bagan dari alur pelayanan perlu ditempatkan di tempat strategis agar mudah dilihat pengguna layanan, didesain secara menarik dengan bahasa yang sederhana dan gambargambar yang memudahkan pemahaman pengguna pelayanan;

4) Unit atau bagian pengaduan masyarakat. Yang dimaksud adalah satuan, unit atau bagian yang berfungsi menerima segala bentuk pengaduan masyarakat. Satuan ini wajib merespons dengan baik semua bentuk pengaduan, menjamin adanya keseriusan dari penyedia layanan untuk menanggapi keluhan dan masukan. Ia juga berperan untuk mengevaluasi system pelayanan yang ada. Salah satu peran penting dari unit pengaduan masyarakat ialah dalam riset dan pengembangan sistem pelayanan;

5) Survai pengguna layanan; Di Indonesia, survai pengguna layanan kebanyakan masih terbatas dilakukan oleh perusahaan swasta dalam bentuk survai pelanggan (customer survey). Kontrak Pelayanan mengharuskan dilakukannya survai pengguna layanan bagi organisasi publik. Tujuannya ialah untuk mengetahui aspirasi, harapan, kebutuhan dan permasalahan yang dihadapi masyarakat. Hasil survei digunakan untuk memperbaiki sistem penyelenggaraan pelayanan publik di masa mendatang sesuai harapan masyarakat. Yang diharapkan dari adanya survai pengguna layanan itu ialah adanya hubungan baik dan tingkat kepercayaan pengguna terhadap penyedia layanan.

Perubahan kontrak merupakan hasil dari interaksi yang sangat intens dan dinamis di antara customers dan providers. Kontrak menggambarkan keseimbangan antara tingginya aspirasi 
dengan kapasitas birokrasi untuk melakukannya. Oleh karena itu, perlu diidentifikasi kelompok pengguna (user group) atau pemangku kepentingan. Masyarakat/ warga seringkali mempunyai tuntutan dan ekspektasi yang tinggi terhadap pelayanan. Karena pelayanan yang ada selama ini bersifat highly rule driven dan sangat terkendala dengan prosedur seperti yang telah disampaikan di atas. Dan juga terkendala dengan kapasitas dan kualitas sumberdaya manusia pelaksana.

Dengan demikian, Citizen Charter sesungguhnya telah menawarkan banyak harapan terjadinya perubahan dalam pelayanan. Pemerintah semakin dituntut untuk transparan pada warga pengguna pelayanan dan stakeholders lainnya. Hal lainnya yang juga menjadi point penting dari pendekatan ini adalah transformasi budaya kepemerintahan, dari budaya kekuasaan ke budaya melayani akan cepat berlangsung. Dalam pendekatan Citizen Charter, pihak penyedia layanan dituntut untuk dapat menjunjung tinggi etika pelayanan. Mulai dari yang paling dasar, seperti sapaan, ramah,senyum merupakan masalah budaya yang tidak mudah ditransformasikan ke dalam birokrasi pemerintah. Belum lagi birokrasi pemerintah selama ini juga memposisikan warga sebagai 'orang yang tidak baik', karena harus selalu dikontrol dengan ketat. Sehingganya dalam era Citizen Charter ini, warga pengguna dan stakeholders pelayanan haruslah ditempatkan pada posisi lebih baik, yakni sebagai mitra. Karenanya juga dalam memberikan pelayanan harus mulai partisipatif dalam menentukan aturan main penyelenggaraan pelayanan.

\section{B. Penerapan Teknologi Informasi dan Komunikasi}

Penerapan Teknologi Informasi dan Komunikasi (TIK) atau yang lebih dikenal dengan sebutan e-governance merupakan strategi berikutnya dalam memulihkan kepercayaan public dan meningkatkan pelayanan publik. Pelayanan public melalui cara ini selain mempercepat dan menghemat waktu, pengguna layanan juga tidak tidak harus menyediakan waktu bertatap muka kepada pelayan public. Dari segi tempat, warga gampong sebagai pengguna pelayanan administrasi akan dengan mudah mengakses tentang syarat-syarat, prosedur, waktu dan biaya yang harus dikeluarkan. Dalam jangka panjang, program ini dapat diterapkan bekerjasam dengan pemerintah Kabupaten atau institusi swasta yang ada. Misalnya, di kabupaten Aceh Barat, gampong-gampong dan /atau kecamatan yang ada dikabupaten ini dapat bekerjasama dengan Perguruan Tinggi yanga ada seperti Universitas Teuku Umar (UTU) khususnya program Studi Ilmu Komunikasi. Gampong-gampong yang ada di kecamatan, bahkan yang ada dikabupaten Aceh Barat dapat dikerjasmakan dengan IT UTU.

Melalui penerapan TIK, tidak saja pelayanan public yang dapat ditingkatkan, melainkan potensi dan objek wisata dari setiap gampong juga dapat ditampilkan. Dengan demikian, para investor ataupun calon wisatawan akan sangat mungkin untuk menanamkan modalnya atau akan melakukan kunjungan wisata ke gampong tersebut.

Syarat berikutnya adalah bagaimana mencegah resitensi aparatur pemerintah dalam menerapkan TIK/ICT. Tidak jarang pula muncul resitensi karena adanya anggapan bahwa aparatur tersebut akan tersingkir karena tidak mampu menguasai TIK/ICT. Resistensi dapat pula terjadi karena dengan penerapan TIK/ICT oknum aparatur gampong yang selama ini sudah nyaman dengan pelayanan langsung dengan warga gampong, karena dengan demikian yang bersangkutan dapat memperoleh "sesuatu" akan berusaha agar TIK/ICT tidak diterapkan.

\section{SIMPULAN \\ Simpulan}

Gampong sebagai pemerintahan terendah dalam struktur pemerintahan di Indoensia telah lama memiliki otonomi dalam proses pemerintahannya. Salah satu bukti bahwa gampong telah lama memiliki otonomi adalah dengan dilakukannya pemilihan Keuchik (Kepala Desa) secara langsung. 
Ketika presiden/ wakil presiden, Gubernur/wakil gubernur, dan bupati/walikota masih dipilih oleh Majelis Permusyawaratan Rakyat dan Dewan Perwakilan Rakyat Daerah, Keuchik sudah dipilih secara langsung oleh rakyat gampong. Masalahnya, dalam dinamika politik yang terjadi, peran dan posisi gampong bergeser, sejalan berubahnya peraturan yang mengatur gampong/desa.

Undang-Undang No. 6 Tahun 2014 tentang Desa, telah mengembalikan keotonomian desa. Desa kembali mengatur dan mengurus rumah tangganya sendiri dan memiliki ruang untuk melakukan inisiatif dan prakarsa dalam proses pemerintahan, termasuk dalma hal pelayanan public. Alokasi Dana Desa (ADD) yang sangat besar dan berarti itu, paling tidak mampu untuk mendorong proses pembangunan di gampong, termasuk pelayanan administrasi kependudukan dan lain-lain.

Sebagai pelayan public, keuchik bersama perangkatnya harus mampu memberikan pelayanan yang bermutu. Selain itu, mereka juga harus mampu melibatkan masyarakat dalam proses pelayanan tersebut. Banyak cara yang dapat dilakukan dalam rangka meningkatkan partisipasi dan kualitas pelayanan public, di antaranya menerapkan kontrak pelayanan (citizen charter) dan teknologi informasi dan komunikasi. Selain kedua strategi tersebut, Keuchik dan perangkatnya, dapat pula mencari dan melakukan inovasi-inovasi lain.

\section{REFERENSI}

Arnstein, Sherry P., (1969), A Ladder of Citizen Participation, AIP Journal, July 1969, hal 216224

Chambers, Robert. 1988. Pembangunan Desa Mulai dari Belakang. Jakarta: LP3ES

Dwiyanto, Agus (edit.). 2005. Mewujudkan Good Governance Melalui Pelayanan Publik. Yogyakarta: Gajah Mada University Press.

Dwiyanto, Agus. 2011. Mengembalikan Kepercayaan Publik Melalui Reformasi Birokrasi. Jakarta: Gramedia

Ife, Jim dan Frank Tesoriero, (2008), Community Development: Alternatif Pengembangan Masyarakat di Era Globalisasi , Yogyakarta: Pustaka Pelajar

M. Busrizalti, 2013, Hukum Pemda : Otonomi Daerah dan Implikasinya. Cet. 1, UTU Press, Yogyakarta, h.140

Osborne, David dan Plastrik, Peter. 2004. Memangkas Birokrasi: Lima Strategi Menuju Pemerintahan Wirausaha. Jakarta: PPM.

Permenpan No. 13/2009 Tentang Pedoman Peningkatan Kualitas Pelayanan Publik Dengan Partisipasi Masyarakat

Pramusinto, Agus. 2006. Inovasi-inovasi Pelayanan Publik untuk pengembangan Ekonomi Lokal: Pengalaman Beberapa Daerah. Jurnal Kebijakan dan Administrasi Publik (JKAP), 10(1): 1-18.

Purwanto, E.A. 2005. Pelayanan Publik Partisipatif, dalam Dwiyanto, Agus (edit). Mewujudkan Good Governance Melalui Pelayanan Publik. Yogyakarta: Gajah Mada University Press.

Subarsono, A.G. 2005. Pelayanan Publik yang Efisien, Responsif, dan non partisan, dalma Dwiyanto, Agus (edit.). Mewujudkan Good Governance Melalui Pelayanan Publik. Yogyakarta: Gajah Mada University Press.

Undang-Undang Nomor 06 Tahun 2014 tentang Desa

Undang-Undang Nomor 25 Tahun 2009 tentang Pelayanan Publik

Undang-Undang Nomor 23 Tahun 2014 tentang Pemerintahan Daerah

Zeithml, V,A, et.al. 1990. Delivering Quality Service: Balancing Customer Perceptions and Expectations. New York: The Three Press. 